\title{
Profil Berpikir Kritis IPA Siswa Kelas VIII SMP Negeri di Kota Ende Berdasarkan Prespektif Gender
}

\author{
Aloisius Harso ${ }^{1}$, Jumilah Gago ${ }^{2}$ \\ 1 Program studi Pendidikan Fisika, Universitas Flores \\ JIn. Sam Ratu Langi No.XX , Kelurahan Paupire Ende Flores \\ 2 Program studi Pendidikan Biologi, Universits Flores \\ JIn. Sam Ratu Langi No.XX, Kelurahan Paupire Ende Flores \\ E-mail: harsoalo4@gmail.com¹, jumilah88gago@gmail.com²
}

\begin{abstract}
Abstrak
Tujuan penelitian ini adalah untuk mengetahui profil kemampuan berpikir kritis IPA berdasarkan gender untuk siswa kelas VIII SMP Negeri di Kota Ende. Populasi dalam penelitian ini adalah seluruh siswa kelas VIII SMP Negeri dalam kota Ende tahun pelajaran 2017/2018, sebanyak 804 orang dan sampelnya terdiri 10\% dari populasi yakni sebanyak 80 orang. Teknik pengambilan sampel dalam penelitian ini adalah random sampling. Data yang diperoleh berupa nilai skor soal tes berpikir kritis IPA. Analisis data dilakukan dengan analisis statistik deskriptif. Hasil penelitian menunjukkan bahwa rerata kemampuan berpikir kritis IPA siswa adalah 66,84 berada pada kategori sedang atau cukup kritis. Sedangkan jika berdasarkan prespektif gender maka kelompok wanita memiliki rerata kemampuan berpikir kritis lebih tinggi dari kelompok Pria, dimana untuk wanita sebesar 68,56 yang berada pada kategori tinggi atau kritis sedangkan untuk pria sebesar 62,03 berada pada kategori sedang atau cukup kritis.
\end{abstract}

Kata kunci: Berpikir Kritis Sains, Gender.

\begin{abstract}
The aims of this research is was to find out the profile of overall science critical thinking ability and based on the gender of viii grade students of SMPN at Ende city. This research was a descriptive research. The population of this research were all the VIII grade students of SMPN at Ende city academic year 2017/2018. As many as 804 students and the sample were $10 \%$ of the populations, they were 80 students. This research used random sampling technique. The data were obtained from the score of science critical thinking ability. The data were analyzed by using descriptive analysis. the result shows that the average of science critical thinking ability of students was 66,84 which is categorized as medium or critical enough. Meanwhile, based on the gender perspective, the female group obtained the average as 68,56 which is categorized as high or critical. Meanwhile, male obtained the 62,03 which is categorized as medium or critical enough.
\end{abstract}

Keywords: Critical Thinking of Science, Gender

\section{PENDAHULUAN}

Kurikulum 2013 dilaksanakan supaya kegiatan pembelajaran berorientasi pada penggalian dan pengembangan potensi diri siswa secara maksimal agar menyiapkan siswa menjadi insan yang berkompetensi dan berkarakter. Salah satu potensi yang perlu diberdayakan adalah berpikir kritis dan kreatif. Peserta didik yang memiliki keterampilan berpikir kritis dan kreatif selalu berusaha menemukan solusi terbaik dari dalam diri saat menghadapi suatu persoalan sehingga menghasilkan keputusan yang bijak bagi dirinya terutama menghadapi segala bentuk tantangan teristimewa tantangan dalam era industri 4.0 saat ini.

Berpikir merupakan suatu kegiatan mental untuk membangun dan memperoleh pengetahuan, untuk mengambil keputusan, membuat perencanaan, memecahkan masalah, serta untuk menilai tindakan (Maulana, 2008). Kemampuan berpikir dapat 
dikelompokkan menjadi kemampuan berpikir dasar dan kemampuan berpikir tingkat tinggi. Kemampuan berpikir tingkat tinggi dapat dikelompokkan menjadi kemampuan berpikir kritis dan kemampuan berpikir kreatif. Kemampuan berpikir kritis (critical thinking)/ CT meliputi berpikir logis dan rasional (membandingkan, klasifikasi, sebab/akibat, analogi, menge-mukakan rangkaian, deduktif, induktif, perencanaan, hipotesis, dan mengkritisi). Kemampuan berpikir kreatif, yaitu mengkreasi sesuatu yang baru atau orisinil (gagasan orisinil, elaborasi, dan modifikasi). Kompetensi berpikir kritis merupa-kan pengetahuan, keterampilan dan sikap dasar yang direalisasikan dalam kebiasaan berpikir dan bertindak seperti interpretation, analysis, inference, explanation, evaluation and selfregulation. Tiga faktor utama yang tercakup dalam belajar berpikir kritis yaitu: teori, latihan dan sikap. Berpikir kritis adalah sebuah proses berpikir yang kompleks dan melibatkan banyak hal. Berpikir kritis merupakan aktivitas mental dalam mengevaluasi suatu argumen atau proposisi dan membuat keputusan yang dapat menuntun diri seseorang dalam mengembangkan kepercayaan dalam melakukan tindakan (Ennis, 1996). Hal senada juga diungkapkan oleh Semerci (2005) bahwa berpikir kritis adalah kecenderungan dan kemampuan untuk terlibat dalam sebuah aktivitas, merefleksi, dan tidak mudah percaya (skeptis).

Ciri-ciri orang CT yang baik dalam pengetahuan, kemampuan, sikap dan kebiasaan yaitu: (1) menggunakan fakta secara teliti dan jujur, (2) mengorgani-sasikan pemikiran-pemikiran dan mengartikulasi secara ringkas dan secara koheren, (3) membedakan antara simpulan yang valid dan tidak valid secara logika, (4) menyingkirkan pendapat/ keputusan tanpa fakta-fakta untuk mendukung sebuah keputusan, (5) memahami perbedaan antara alasan dan rational, (6) berusaha mengantisipasi konsekuensi yang mungkin dari tindakan-tindakan alternatif yang dilakukan, (7) memahami tingkat kepercayaan ide-ide, (8) melihat kesamaan dan analogi-analogi yang tidak cukup jelas, (9) dapat belajar secara independen dan memilih kemauan yang tinggi untuk melakukan sesuatu, (10) kebiasaan bertanya pada pandangan sendiri dan berusaha untuk memahami asumsi dan implikasi dari pandangan tersebut, (11) menyadari fakta yang dia pahami selalu terbatas dari pada yang tampak, (12) lebih banyak menekankan teknik problem solving dalam belajar, (13) dapat menyusun masalah informal yang disuguhkan menggunakan teknik formal problem solving dan (14) dapat memilah sebuah argument verbal dari yang tidak relevan dan esensial, (15) mempertimbangkan tingkat kesalahan dari pandangannya, kemungkinan bias pandangannya tersebut, dan bahaya dari menekankan fakta menurut pilihan perorangan, (16) sensitif terhadap perbedaan antara validitas dari keyakinan dan intensitas (Raymond dalam Schafersman, 1991).

Berpikir kritis tidak dapat diajarkan melalui metode ceramah, karena berpikir kritis merupakan proses aktif. Keterampilan intelektual dan berpikir kritis mencakup berpikir analisis, berpikir sintesis, berpikir reflektif dan sebagainya harus dipelajari melalui aktualisasi penampilan. Berpikir kritis dapat diajarkan dengan cara kegiatan laboratorium, inkuiri, term paper, pekerjaan rumah yang menyajikan berbagai kesempatan untuk menggugah berpikir kritis, dan ujian yang dirancang untuk mempromosikan keterampilan berpikir kritis (Schafersman, 1991).

Sadia (2009) menyatakan kemampuan dan keterampilan berpikir kritis dapat dikembangkan dengan memperhatikan tiga aspek yaitu aspek afektif, konatif, dan aspek behavioral. Dimulai dengan penyajian suatu stimulus eksternal berupa suatu argumen atau proposisi yang harus dievaluasi. Disposisi afektif akan memberi dorongan untuk bertindak sebagai tuntunan prilaku berdasarkan pemikiran kritis. Aspek konatif sebagai komponen proses regulasi diri harus diaktifkan dalam upaya pengembangan dan implementasi rencana tindakan. Tindakan yang harus berdasarkan umpan balik dari lingkungan dan pengetahuan prosedural yang berkaitan. Karena itu jelas bahwa pengetahuan prosedural akan sangat berperan dalam pengembangan kemampuan dan keterampilan berpikir kritis. Namun demikian, pengetahuan 
deklaratif juga ikut memberi andil dalam pengembangan kemampuan berpikir kritis. Peningkatan kemampuan dan keterampilan berpikir kritis lebih cocok jika guru menggunakan metode pembelajaran yang menekankan pada pengetahuan prosedural melalui pemodelan atau personal.

Kompetensi berpikir kritis dapat ditingkatkan melalui latihan. Langkah-langkah yang dapat membantu siswa dalam meningkatkan kompetensi berpikir kritis adalah (1) menentukan masalah atau isu nyata, proyek atau keputusan yang betul-betul dipertimbangkan untuk dikritisi; (2) menentukan poin-poin yang menjadi pandangan; (3) memberikan alasan mengapa poin-poin tersebut yang dipertimbangkan untuk dikritisi; (4) membuat asumsi-asumsi yang diperlukan; (5) bahasa yang digunakan harus jelas; (6) membuat alasan yang mendasari dalam faktafakta yang meyakinkan; (7) mengajukan kesimpulan; (8) menentukan implikasi dari kesimpulan tersebut (Johnson, 2002). Johnson dan Schafersman menyatakan tujuan dari berpikir kritis adalah untuk mencapai pemahaman yang mendalam (deep understanding) dan dalam pembelajaran sains adalah untuk meningkatkan keterampilan berpikir siswa sekaligus menyiapkan para siswa agar mampu mengarungi kehidupan sehari-hari.

Ennis (1996) mengelompokkan berpikir kritis kedalam 6 aspek yang dikembangkan lagi menjadi 12 indikator yakni sebagai berikut: (1) merumuskan masalah dengan indikator (a) memformulasikan pertanyaan yang mengarahkan investigasi 2) pemberian penjelasan sederhana (elementary clarification) dengan indikator (a) pemusatan pertanyaan. (b) analisis pertanyaan dan bertanya (c) memberikan jawaban pertanyaan tentang suatu penjelasan atau pernyataan. (2) mengkonstruksi keterampilan dasar (basic support) dengan indikator (a) mempertimbangkan referensi yang diperoleh, (b) mengamati serta mempertimbangkan suatu laporan hasil observasi, 3) kesimpulan (interfence) dengan indikator (a) mendeduksi atau mempertimbangkan hasil deduksi (b) mendeduksi atau mempertimbangkan hasil deduksi, (c) membuat serta nilai pertimbangan. 4) membuat penjelasan lanjutan (advance clarification),dengan indikator pengidentifikasian istilah-istilah dan definisi pertimbangan (b) mengidentifikasi hasil asumsi serta 5) pengaturan strategi dan taktik (strategy and tactics) dengan indikator (a) menentukan aksi dan b) berinteraksi dengan orang lain.

Selanjutnya William (2011) menguraikan bahwa sains merupakan tempat yang subur untuk menumbuhkan kembangkan kemampuan berpikir kritis siswa. Hal ini dikarenakan hubungan antara pemikiran ilmiah dan kemampuan berpikir kritis. "Critical thinking is a cognitive activity, associated with using the mind' yang artinya berpikir kritis merupakan kegiatan kognitif, yaitu berkaitan dengan bagaimana menggunakan pikiran. Proses penemuan suatu teori atau hukum baru dalam sains selalu menggunakan metode ilmiah yang merupakan reprensentasi dari kemampuan berpikir kritis.

Dengan demikian pemberdayaan keterampilan berpikir kritis pada siswa sangat mendesak dilakukan dan dapat terintegrasi melalui metode-metode pembelajaran yang terbukti mampu memberdayakan keterampilan berpikir kritis siswa (Hadi: 2009). Laporan hasil penelitian yang dilakukan oleh Harso dkk (2014), menunjukkan bahwa $85 \%$ soal-soal yang dibuat oleh Guru-guru IPA SMP di kota Ende masih pada level kemampuan berpikir tingkat dasar yakni pada level $\mathrm{C}_{1}, \mathrm{C}_{2}$ dan $\mathrm{C}_{3}$ hanya $15 \%$ berada pada level berpikir tingkat tinggi. Padahal sekolah-sekolah tersebut sudah ada yang menerapkan kurikulum 2013 dengan menggunakan pendekatan saintifik dan ada pula sekolah yang masih menggunakan KTSP tetapi menggunakan model pembelajaran inovatif seperti model inquri, model problem based learning, model cooperatif learning dan pembelajaran berbasis proyek dan lain-lain. Pendekatan saintifik mampu meningkatkan kemampuan berpikir efektif (Asta, Agung, \& Widiana, 2015). Model pembelajaran inovatif (model project based learning) mampu meningkatkan kemampuan berpikir tingkat tinggi (Aksani \& Purwanto, 2015).

Perbedaan jenis kelamin merupakan salah satu perbedaan yang ada pada peserta 
didik. Beberapa hasil penelitian menunjukkan bahwa tidak adanya perbedaan hasil berpikir kritis antara siswa wanita dan pria (Rubin, 1993; Myers, 2006; \& Yousefi, 2016) sedangkan hasil penelitian lain seperti Ricketts (2004) menunjukan nilai wanita lebih tinggi dari nilai pria dalam hal kemampuan berpikir kritis. Penelitian ini merupakan penelitian awal yang bertujuan untuk mengungkap gambaran kemampuan berpikir kritis sains peserta didik lewat penyelesaian soal-soal mengacu pada dimensi berpikir kritis yang dikembangkan oleh Ennis (1996) dengan judul penelitian "Profil berpikir Kritis IPA Siswa Kelas VIII SMP Negeri di Kota Ende berdasarkan prespektif gender".

\section{METODE}

Jenis penelitian yang digunakan adalah penelitian deskriptif. Penelitian ini dilaksanakan di SMP Negeri di Kota Ende yakni: SMPN 1 Ende dan SMPN 2 Ende Kecamatan Ende Tengah, SMPN 1 Ende Selatan Kecamatan Ende Selatan, SMPN 2 Ende Selatan Kecamatan Ende Utara. Penelitian dilaksanakan selama dua minggu pada bulan Maret tahun 2018 yakni mulai tanggal 15 Maret sampai dengan tanggal 29 Maret tahun 2018. Instrumen yang digunakan dalam penelitian ini adalah soal tes essay kemampuan berpikir kritis. Dimensi kemampuan berpikir kritis yang digunakan dalam penelitian ini adalah dimensi berpikir kritis menurut Ennis (1996) yang terdiri atas enam dimensi yaitu 1). merumuskan masalah, 2). memberikan penjelasan sederhana, 3). membangun keterampilan dasar. 4), mengatur strategi dan taktik, 5) menyimpulkan,dan 6) memberi penjelasan lanjut yang diuraikan lagi dalam 12 indikator. Karena penelitian ini adalah penelitian deskriptif hanya mengukur profil kemampuan berpikir kritis IPA siswa maka uji instrumen yang digunakan dalam penelitian ini terbatas pada uji validitas isi. Uji validitas isi dilakukan oleh 2 orang ahli dan dianalisis menggunakan Tabel Gregory (Gregory, 2000). Jumlah butir soal yang dibuat dalam penelitian ini adalah 25 butir soal. Setelah dilakukan uji validitas isi maka 20 butir soal dinyatakan diterima dan bisa diberikan pada kelas sampel penelitian.
Selanjutnya data yang diperoleh dari kelas sampel dianalisis menggunakan statistik deskriptif. Dalam analisis statistik deskriptif teknik yang digunakan adalah rata-rata (mean), median, modus, standar deviasi, skor minimum dan skor maksimum. Penyajian data dalam tabel distribusi frekuensi skor perolehan dan presentase skor perolehan serta frekuensi kumulatif hasil. Analisis ini dimaksud untuk mendeskripsikan karakteristik distribusi skor responden untuk masing-masing dimensi.

1. Analisis Data Soal Tes Uraian

Persentase dimensi yang dimiliki siswa menggunakan rumus:

$$
P=\frac{\text { frekuensi per individu }}{\text { Jumlah individu }} \times 100 \%
$$

Dengan $\mathrm{P}$ adalah persentase jawaban individu.

2. Kategori kemampuan berpikir kritis IPA siswa berdasarkan soal tes.

Tabel 1. Penilaian Tingkat Kemampuan Berpikir Kritis Siswa

\begin{tabular}{ccc}
\hline $\begin{array}{c}\text { Interval } \\
\text { kelas }\end{array}$ & Penilaian & Kategori \\
\hline $80-100$ & Sangat Tinggi & Sangat Kritis \\
$68-79$ & Tinggi & Kritis \\
$56-67$ & Sedang & Cukup Kritis \\
$44-55$ & Rendah & Kurang kritis \\
$\leq 43$ & Sangat Rendah & Tidak kritis \\
\hline
\end{tabular}

(Diadaptasi dari Nurkancana, W., \& Sunartana, 1992 )

\section{HASIL DAN PEMBAHASAN}

\section{HASIL}

\section{Data Critical Thinking (CT) IPA Siswa}

Berdasarkan data kemampuan CT IPA yang diolah, maka diperoleh ringkasan data seperti pada Tabel 2 berikut.

Tabel 2. Data Statistik Deskriptif CT IPA siswa

\begin{tabular}{ccc}
\hline Nomor & Stastistik deskriptif & Nilai \\
\hline & Sampel & 80 \\
1 & Jangkuan & 42.50 \\
2 & Nilai minimum & 42.50 \\
3 & Nilai maksimun & 85.00 \\
4 & Rerata & 66.84 \\
5 & Standar deviasi & 9.114 \\
6 & Varians & 83.069 \\
\hline
\end{tabular}

Dari Tabel 2, menunjukan bahwa 
kemampuan berpikir kritis IPA siswa memiliki rerata 66.84 yang digolongkan kedalam kategori sedang atau cukup kritis.

Bila dilihat dari sebaran data yang mengacu pada kategorisasi kecenderungan yang telah dikonversikan maka distribusi frekuensi tingkat kemampuan berpikir kritis IPA siswa dapat disajikan dalam Tabel 3 berikut.

Tabel 3. Kategori Tingkat Berpikir Kritis IPA Siswa SMP Negeri dalam Kota Ende

\begin{tabular}{ccc}
\hline $\begin{array}{c}\text { Interval } \\
\text { kelas }\end{array}$ & Kategori & $\begin{array}{c}\text { Frekuensi / } \\
\text { Persentase }\end{array}$ \\
\hline $80-100$ & Sangat kritis & $8(10 \%)$ \\
$68-79$ & Kritis & $28(35 \%)$ \\
$56-67$ & Cukup kritis & $30(37.5 \%)$ \\
$44-55$ & Kurang kritis & $13(16.25 \%)$ \\
$\leq 43$ & Tidak kritis & $1(1.25 \%)$ \\
\hline & Jumlah & $80(100 \%)$
\end{tabular}

Dari Tabel 3 menunjukan bahwa kategori tingkat kemampuan berpikir kritis IPA siswa yakni 1 siswa $(1,250025)$ tidak kritis, 13 siswa $(16,25 \%)$ berkategori kurang kritis, 30 siswa $(37.5 \%)$ berkategori cukup kritis, 28 siswa (35\%) berkategori kritis, dan 8 siswa (10\%) berkategori sangat sangat kritis. Untuk memperjelaskan deskripsi data dapat dilihat pada Gambar 1. berikut.

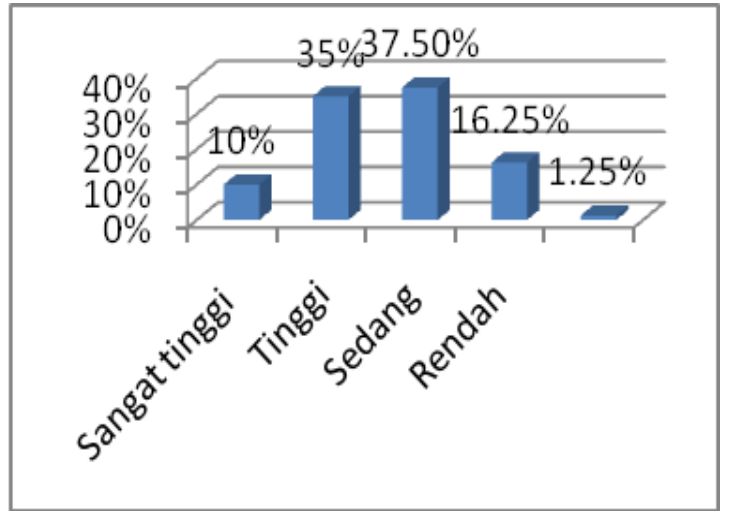

Gambar 1. Diagram batang kategori tingkat CT IPA siswa

\section{Data Penguasaan CT IPA Berdasarkan Gender}

Berdasarkan hasil analisis deskriptif yang disebarkan kepada para responden pria dan wanita mendapatkan data seperti tersaji pada Tabel 4 berikut.

Tabel 4. Data satatistik deskriptif CT IPA siswa berdasarkan Gender

\begin{tabular}{ccc}
\hline $\begin{array}{c}\text { Statistik } \\
\text { Deskriptif }\end{array}$ & \multicolumn{2}{c}{ Jenis kelamin } \\
\cline { 2 - 3 } & Pria & Wanita \\
\hline Mean & 62,03 & 68,56 \\
Median & 61,25 & 60,62 \\
Modus & 61,25 & 52,5 \\
Std. Deviasi & 9,35 & 8,23 \\
Minimum & 43,75 & 48,75 \\
Maximum & 83,75 & 85.00 \\
\hline
\end{tabular}

Dari Tabel 4 menunjukan bahwa tingkat berpikir kritis sains kelompok pria mempunyai nilai rata-rata 62,03 dan kelompok wanita 68.56 hal ini berarti rerata kelompok wanita lebih tinggi dari pria. Jika merujuk pada Tabel 1 maka tingkat kemampuan berpikir kritis kelompok pria termasuk dalam kategori sedang atau cukup kritis sedangkan untuk kelompok wanita masuk dalam kategori tinggi atau kritis.

Data distribusi tingkat kemampuan berpikir kritis IPA kedua kelompok tersaji dalam Tabel 5 berikut..

Tabel 5. Kategori tingkat penguasaan

kemampuan berpikir kritis IPA siswa berdasarkan jenis kelamin

\begin{tabular}{|c|c|c|c|}
\hline \multirow{2}{*}{$\begin{array}{c}\text { Interval } \\
\text { Kelas }\end{array}$} & \multirow[t]{2}{*}{ Kategori } & Pria & Wanita \\
\hline & & $\begin{array}{c}\text { Frekuensi } \\
\text { (Prensentasi) }\end{array}$ & $\begin{array}{r}\text { Frekuensi } \\
\text { (Presentasi }\end{array}$ \\
\hline $80-100$ & $\begin{array}{l}\text { Sangat } \\
\text { kritis }\end{array}$ & $3(7,5 \%)$ & $5(12,5 \%)$ \\
\hline $68-79$ & Kritis & $12(30 \%)$ & $16(40 \%)$ \\
\hline $56-67$ & $\begin{array}{l}\text { Cukup } \\
\text { kritis }\end{array}$ & $13(32,5 \%)$ & $17(42,5 \%)$ \\
\hline $44-55$ & $\begin{array}{l}\text { Kurang } \\
\text { kritis }\end{array}$ & $11(27,5 \%)$ & $2(5 \%)$ \\
\hline$\leq 43$ & $\begin{array}{l}\text { Tidak } \\
\text { kritis }\end{array}$ & $1(2,5 \%)$ & $0(0 \%)$ \\
\hline $\mathrm{J}$ & nlah & $40(100 \%)$ & $40(100)$ \\
\hline
\end{tabular}

Dari Tabel 5 diperoleh sebaran kemampuan berpikir kritis IPA siswa pria adalah 1 siswa (2,5\%) berkategori tidak kritis, 11 siswa $(27,5 \%)$ kurang kritis, 13 siswa $(32,5 \%)$ cukup kritis, 12 siswa (30\%) kritis dan 3 siswa $(7,5 \%)$ berkategori sangat kritis. Sedangkan 
untuk tingkat kemampuan berpikir kritis IPA siswa wanita yaitu $2(5 \%)$ berkategori kurang kritis, 17 siswi (42,5\%) cukup kritis, 16 siswa (40\%) berkategori kritis, dan 5 siswi (12,5\%) sangat kritis.

Selanjutnya deskripsi data rerata berpikir kritis IPA berdasarkan prespektif gender untuk masing-masing dimensi tersaji dalam Tabel 6 berikut.

Tabel 6. Rerata CT sains siswa untuk setiap dimensi berdasarkan gender

\begin{tabular}{|c|c|c|}
\hline \multirow[t]{2}{*}{ Dimensi } & \multicolumn{2}{|c|}{ Gender } \\
\hline & Pria & Wanita \\
\hline Merumuskan masalah & 65,53 & 64,40 \\
\hline $\begin{array}{l}\text { Memberi } \quad \text { penjelasan } \\
\text { sederhana }\end{array}$ & 63,12 & 64,53 \\
\hline $\begin{array}{l}\text { Membangun keterampilan } \\
\text { dasar }\end{array}$ & 64,41 & 62,81 \\
\hline Mengatur strategi dan taktik & 64,88 & 69,72 \\
\hline Menyimpulkan & 61,56 & 69,38 \\
\hline Memberi penjelasan lanjut & 67,66 & 79,38 \\
\hline
\end{tabular}

Dari Tabel 6, tingkat berpikir kritis IPA kelompok pria menunjukan bahwa dimensi merumuskan masalah memiliki rata-rata nilai 65.53, dimensi memberikan penjelasan sederhana memiliki rata-rata nilai 63,12 , dimensi membangun keterampilan dasar memiliki rata-rata nilai 64,41 , mengatur strategi dan taktik memiliki rata-rata nilai 64,88 menyimpulkan memiliki rata-rata nilai 61,56 , memberi penjelasan lanjut memiliki rata-rata nilai 67,66 . Untuk tingkat kemampuan berpikir kritis IPA kelompok wanita menunjukan bahwa dimensi merumuskan masalah memiliki ratarata nilai 64,40 , memberikan penjelasan sederhana memiliki rata-rata nilai 64,53 , membangun keterampilan dasar memiliki ratarata nilai 62,81 , mengatur strategi dan taktik memiliki rata-rata nilai 69,72 menyimpulkan memiliki rata-rata nilai 69,38 , dan dimensi memberi penjelasan lanjut memiliki rata-rata nilai 79,38 .

\section{PEMBAHASAN}

Berpikir kritis sangat penting untuk dimiliki oleh setiap individu karena berkaitan dengan pengambilan keputusan yang tepat dalam berbagai aktifitas. Hasil penelitian menunjukan bahwa data berpikir kritis IPA siswa SMP Negeri di kota Ende sebanyak 3 siswa $(3,75 \%)$ mempunyai tingkat berpikir kritis IPA sangat rendah atau tidak kritis, 24 siswa (30\%) rendah atau kurang kritis, 33 siswa $(41,25 \%)$ sedang atau cukup kritis, 16 siswa (20\%) tinggi atau kritis, dan 4 siswa (5\%) sangat tinggi atau sangat kritis. Secara keseluruhan nilai rata-rata kemampuan berpikir kritis IPA siswa sebesar 66,84 terletak pada interval 56-67 yang dikelompokkan dalam kategori sedang atau cukup kritis. Jika ditinjau dari perspektif gender maka hasil penelitian menunjukkan bahwa kemampuan berpikir kritis IPA pada kelompok pria memiliki nilai rata-rata 62,03 yang berada pada kategori sedang atau cukup kritis sedangkan pada kelompok wanita memiliki rata-rata 68,56 pada kategori tinggi atau kritis. Hal ini berarti menunjukan bahwa adanya perbedaan berpikir kritis sains antara kelompok pria dan wanita.

Sedangkan data kemampuan CT IPA untuk setiap dimensi menunjukan bahwa untuk aspek merumuskan masalah kelompok Pria dan wanita berada pada kategorial yang sama yakni sedang atau cukup kritis artinya kedua kelompok sama-sama mampu memahami persoalan yang diberikan dan solusi yang ditawarkan dimana kedua kelompok samasama menuliskan hal-hal yang diketahui dari persoalan yang diberikan berupa fakta-fakta yang ada secara jelas dan logis. Untuk dimensi memberikan penjelasan sederhana, kedua kelompok berada pada kategori yang sama yakni sedang atau cukup kritis dimana kelompok pria dan wanita mampu memberikan penjelasan-penjelasan singkat yang masuk akal berdasarkan bukti-bukti yang ada.

Untuk dimensi membangun keterampilan dasar kedua kelompok sama-sama berada pada kategori yang sama yakni kategori sedang atau cukup kritis. Hal ini dapat diketahui dari penggunaan referensi-referensi yang ada untuk membantu menemukan jawaban atas pertanyaan atau pernyataan yang diberikan. Untuk dimensi mengatur strategi dan taktik, kedua kelompok memiliki perbedaan rerata nilai kemampuan CT dimana kelompok perempuan lebih tinggi dari kelompok pria. Hal ini dikarenakan pada kelompok perempuan mampu menggunakan semua jenis data/ 
informasi yang ada secara detail dan berhatihati dan selalu berupaya untuk melakukan pengecekan kembali terhadap jawaban yang sudah dihasilkan sehingga menggunakan waktu relatif lama. Sedangkan pada kelompok Pria hanya menggunakan data/informasi yang penting saja dan tidak berupaya mengkonfirmasi kembali jawaban yang sehingga waktu dibutuhkan relatif singkat. Untuk dimensi menyimpulkan, kedua kelompok memiliki rerata berbeda dimana kelompok wanita berada pada kategori tinggi atau kritis sedangkan kelompok pria berada pada kategori sedang atau cukup kritis hal ini dikarenakan pada kelompok wanita kesimpulan yang ditarik sesuai dengan alasan-alasan yang diberikan dan disajikan cendrung lengkap dan terperinci sedangkan pada kelompok pria kesimpulan sudah sesuai dengan alasan yang diberikan namun datanya kurang lengkap dan tidak terperinci. Pada dimensi memberi penjelasan lanjutan, kelompok wanita berada level atau kategori tinggi atau kritis sedangkan kelompok pria berada pada kategori sedang atau cukup kritis. Adanya perbedaan pada dimensi ini dikarenakan kelompok perempuan mampu memberikan klarifikasi disertai dengan pertimbangan-pertimbangan yang menyakinkan yang disertai data yang memadai, sedangkan pada kelompok pria datadata yang disajikan kurang lengkap.

Sehingga secara keseluruhan tingkat berpikir kritis sains kelompok wanita lebih tinggi dibandingkan dengan kelompok pria dengan selisih rata-rata sebesar 6,53. Adanya perbedaan kemampuan berpikir kritis IPA antara kelompok wanita dan pria karena berbagai faktor diantaranya terdapat perbedaan kemampuan berkomunikasi, dimana terdapat perbedaan struktur otak antara pria dan wanita dalam hal kemampuan pengolahan bahasa. (Pambudiono, Zubaidah, \& Mahanal, 2013). Karena bahasa adalah media penyaluran gagasan atau ide. Penggunaan bahasa yang jelas dan terstruktur merupakan indikasi seseorang memiliki kemampuan berpikir tingkat tinggi. Guilerr (2005) menyatakan wanita memiliki skill yang baik dalam berkomunikasi.

Sasser (2010) menjelaskan bahwa daerah sistem limbik pada pria dan wanita memiliki struktur yang berbeda. Umumnya wanita memiliki hippocampus lebih besar dari pada pria sehingga berpotensi meningkatkan memori penyimpanan jangka panjang yang lebih bagus. Selain itu bagian otak lain yang memiliki struktur berbeda antara pria dan wanita adalah cerebral cortex yang mengontrol berpikir, mengambil keputusan, dan fungsi intelektual, otak wanita menerima sekitar $20 \%$ lebih banyak aliran darah dan memiliki koneksi saraf yang lebih banyak. Hal tersebut memungkinkan wanita mampu menganalisis informasi yang lebih cepat dari pria. Selain itu wanita memiliki kematangan emosional lebih baik dari pria. Sehingga wanita mampu menyelesaikan segala sesuatu dengan lebih berhat-hati.

Secara empirik hasil penelitian ini konsisten dengan temuan penelitian yang telah dilakukan oleh Ricketts (2004) dan Pambudiono dkk (2013) yang menyimpulkan bahwa kemampuan berpikir kritis wanita lekbih tinggi dari pria.

\section{PENUTUP}

Berdasarkan analisis data dan pembahasan maka dapat disimpulkan bahwa: (1) Secara keseluruhan rerata tingkat kemampuan berpikir kritis IPA siswa Kelas VIII SMP Negeri di kota Ende adalah 66,84 berada dalam kategori sedang atau cukup kritis. Sebaran kemampuan berpikir kritis IPA siswa Kelas VIII SMP Negeri di Kota Ende adalah (a) $3,75 \%$ siswa berkategori sangat rendah atau tidak kritis (b) $30 \%$ siswa berkategori rendah atau kurang kritis, (c) $41,25 \%$ siswa berkategori sedang atau cukup kritis, (d) $20 \%$ berkategori tinggi atau kritis, dan (e) hanya 5\% siswa berkategori sangat tinggi atau sangat kritis. (2) Jika ditinjau berdasarkan gender maka rerata kemampuan berpikir kritis kelompok wanita lebih tinggi yakni 68,58 berada pada kategori tinggi atau kritis dibandingkan dengan kemampuan berpikir kritis kelompok pria sebesar 62,03 berada pada kategori sedang atau cukup kritis.

Sesuai dengan hasil penelitian ini, 
diharapkan untuk para guru mata pelajaran IPA agar dalam kegiatan pembelajaran di kelas perlu menerapkan suatu model pembelajaran yang dapat meningkatkan kemampuan berpikir kritis siswa dan dalam penyusunan soal-soal ujian perlu memperbanyak soal berpikir tingkat tinggi.

\section{UCAPAN TERIMAKASIH}

Pada kesempatan ini, penulis ingin menyampaikan rasa terima kasih sedalamdalamnya kepada semua pihak teristimewa buat Ibu Skolastika Amsun Dalus yang telah banyak membantu dan memberikan dorongan agar tulisan ini terselesaikan dengan baik. Ibu Jumilah Gago yang berpartisipasi aktif dalam menyelesaikan penelitian ini serta para Kepala Sekolah dan Guru mata pelajaran IPA yang telah memberikan kesempatan kepada Tim Peneliti untuk melakukan penelitian di sekolahsekolah tersebut.

\section{DAFTAR PUSTAKA}

Aksani, L.,\& Purwanto, J. (2015). Meningkatkan kemampuan berpikir tingkat tinggi mahasiswa pendidikan matematika UMP melalui model Project Based learning pada mata kuliah kalkulus lanjut I. Journal Mathematics Education AlphaMath,1(1), 45-49.

Asta, I. K. R., Agung, A. A. G., \& Widiana, I. W. (2015). Pengaruh Pendekatan Saintifik dan Kemampuan Berpikir Kritis Terhadap Hasil Belajar IPA. MIMBAR PGSD Undiksha, 3(1).

Ennis, R. H (1996). Critical Thinking. USA: Prentice Hall, Inc.

Gregory, R. J. (2000). Psycologycal testing, history, principles, and applications. Boston: Allyn \& Bacon, Inc.

Guiler, J., Ross, A., \& Durndell. (2005). The role of gender in a peer based critical thinking task. Departement of Psychology, Glasgow Caledonian Unversity. Glasgow, Scotland UK.

Hadi. (2009). Pengaruh Penggunaan
Laboratorium Riil dan Laboratorium Virtuil pada Pembelajaran Fisika Ditinjau dari Kemampuan Berpikir Kritis Siswa. Tesis. Tidak Dipublikasikan. Surakarta: Universitas Sebelas Maret.

Harso, A., \& Kaleka, M. (2014). Analisis kemampuan berpikir pada soal-soal UTS IPA yang disusun oleh guru-guru IPA SMP Sekota Ende. Laporan hasil penelitian. Program Studi Pendidikan Fisika FKIP Universitas Flores Ende. Tidak dipublikasikan.

Johnson, E. B., (2002). Contextual teaching and learning: what it is and why it's here to stay. United States of America: Corwin Press, INC.

Maulana. (2008). Pendekatan Metakognitif Sebagai Alternatif Pembelajaran Metematika Untuk Meningkatkan Kemampuan Berpikir Kritis Mahasiswa PGSD. Jurnal penelitian Pendidikan, 8(1). 21-28.

Myers, B.E., \& Dyer, J.E. (2006). The Influence Of Student Learning Style On Critical Thinking Skill. In Journal of Agricultural Education, 47 (1), 43-52.

Nurkancana, W., \& Sunartana, P.P.N. (1992). Evaluasi hasil belajar. Surabaya: Penerbit Usaha Nasional.

Pambudiono, A., Zubaidah, S., \& Mahanal, S. (2013). Perbedaan Kemampuan Berpikir dan Hasil Belajar Biologi Siswa Kelas X SMA Negeri 7 Malang Berdasarkan Jender dengan Penerapan Strategi Jigsaw. Jurnal Pendidikan Hayati, 1 (1).

Ricketts, J.C., \& Rudd, R. (2004). Critical Thinking Skills of FFA Leaders: Journal of Southern Agricultural Education Research, 54 (1), 21-33.

Sadia, I W., Subagia, W., \& Natajaya, I N. (2009). Pengembangan model pembelajaran dan perangkat pembelajaran untuk meningkatkan keterampilan berpikir kritis (critical thinking skills) siswa Sekolah Menengah Pertama (SMP) dan Sekolah Menengah Atas (SMA). Laporan Penelitian (tidak diterbitkan). Jurusan Pendidikan Fisika Universitas Pendid'ikan Ganesha.

Schafersman, S. D. (1991). An introduction to critical thinking. Tersedia pada 
http://www.freeinquary.com/criticalthinking.html. Diakses tanggal 27 januari 2018.

Sasser, L. (2010). Brain Differences between Genders. Gender Differences in Learning, Genesis 5,1-2. http://www.faccs.org/assets/Conventio ns/Convention10/Workshops/SasserGender-Differences-in-Learning.pdf, diakses tanggal 13 Maret 2017.

Semerci, C. (2005). The influence of the critical thinking skills on the Students'Achievement. Pakistan Journal of Social Sciences, 3(4), 598-602.
Yousefi, S., \& Mohammadi, M. (2016). Critical Thinking and Reading Comprehension among Postgraduate Students: The Case of Gender and Language Proficiency Level. Journal of Language Teaching and Research, 7(4), 802-807, July 2016. http://dx.doi.org/10.17507/iltr.0704.23.

William, J.D. (2011). How science works: Teaching and learning in the science classroom. Chennai: Continuum. 